\section{SOME MYANMAR HISTORICAL FICTION AND THEIR HISTORICAL CONTEXT*}

\section{U Than Htut \& U Thaw Kaung **}

We read through a number of Myanmar historical novels and selected a few for presentation in our paper. The historical novels we are giving as examples of Myanmar historical fiction have been checked with some of the main texts of Myanmar history.

The Myanmar historical texts we have used are a few original inscriptions (mainly on lithic / stone), and also the old chronicles like U Kala's (c. 17141733) Maha Yazawin-gyi ${ }^{1}$ the Hmannan Maha Yazawin (The Glass Palace (hronicle) $)^{2}$, compiled by a commission

* This paper was read at an international Conference on Texts and Contexts in Southeast Asia, held in Yangon, Dec. 2001. The subject of our paper is Myanmar historical fiction.

**Members of the Myanmar Historical Commission and retired Chief Librarians (T.H. of the National Library, and T.K. of the Universities Central Library.)

1 U kala. Maha Yazawin-gyi .... Burma Research Society ed. ... (Yangon: Hanthawaddy, 1960-1961) (reprint). 3v. Burma Research Society ed., edited by Saya Pwa, 2 vols. $1^{\text {st }}$ published v.1 (1926); v.2 (1932); v.3 $1^{\text {st }}$ pub. 1961 ed. by U Khin soe.

2 Hman-nan Maha Yazawin-daw-gyi ... (The Glass Palace Chronicle). Mandalay: Mandalay Pitaka Book Depot, 1936. 3 vols.

${ }^{3}$ Konbaung-zet Maha Yazawin-daw gyi ... $3^{\text {rd }}$ ed. (Yangon: Ledi Mandaing Press, 1968). $3 v .1^{\text {st }}$ published. 1921 . set up by King Bagyidaw (1819-1837) in 1829 and the Konbaung-zet Maha Yazawin-daw-gyi $i^{3}$, compiled by $\mathrm{U}$ Maung Maung Tin (KSM). We have also used some local histories like the Taungoo Yazawin ${ }^{4}$ and the Than-lyin Yazawi ${ }^{5}$, and a historical text compiled and translated from non-Myanmar languages, the Pawtugi Yazawin ${ }^{6}$ (History of the Portuguese, with special reference to Asia and Myanmar).novel was published to year

The historical fiction which we have examined are mainly novels written from 1919, when the first Myanmar historical novel was published, to year 2000 , a period of about 80 years. Our paper is by no means a survey of this genre in our country; there are already a few such accounts in the Myanmar language ${ }^{7}$.

For the historian, original texts are the most important sources, but even contemporary stone inscriptions like the well-known inscriptions of King Kyan-

4 Taungoo Yazawin; compiled by Shin Nyana-thikhan-gyi; ed. by Saya Pwa. (Taungoo: Kaytumadi Press, 1924).

${ }^{5}$ Than-lyin Yazawin. [History of Syriam]. Yangon: Thitsawardi Thadinsa Press, 1925.

${ }^{6}$ Pawtugi Yazawin. (Yangon: Thuriya Press, $1918)$. Written in early $19^{\text {th }}$ century by Father Ignazio de Brito and Johannes Moses, a.k. a. Baba Sheen.

${ }^{7}$ See (1) Paragu (U Hla Kyaing), "Thamaing nauk-khan Myanmar wuthtu," [Myanmar novels with historical backgrounds] in Wuthtu shay sardan mya [Papers on Novels]. Vol. 1. (Yangon: Sarpay Beikman, 1981)p. 76-128.

(2) Tin Htun, U Yazawin saing-yar Myanmar wuthtu mya (1885-1947) [Myanmar novels about history]. (Yangon: University of Yangon, 1982). Unpublished M.A. in Myanmar Literature thesis. 389 p. 
zittha (AD 1084-1112), where, in giving his genealogy, the King wrote that he was related to Rama (an avatar of the Hindu God Vishnu) in a previous existence, contain what would now be regarded as legendary tales which are fictitious. Aldous Huxley who read The Glass Palace Chronicle (the parts mostly on Bagan, translated into English by U Pe Muang tin and Prof. G. H. Luce) remarked rather harshly that "it is a collection of fabulous anecdotes." 8

We have compared some historical texts with their relevant fiction to bring out in the context how true to (historical) facts the Myanmar novelists have been in depicting a particular period, incident or character.

Myanmar historical fiction is similar to English and American historical fiction in that it takes quite a wide variety of forms. At the lowest level the novels are nothing but adventure or love stories presented in period costumes and the story supposedly taking place in a certain period of Myanmar's historical past, though it could have been in any other similar country or time.

At the very best Mynmar historical fiction depicts what life was like in an actual period, teeming with personalities and events of history, giving "the colour and pattern of life in the past and to give immediate reality, charm and meaning to its human figures."

${ }^{8}$ Aldous Huxley. Jesting Pilate, the Diary of a Journey. (London: Chato \& Windus, 1948) (1957 reprint). p. 169. $1^{\text {st }}$ pub. in 1926.

${ }^{9}$ Helen E. Haines. Living with Books... ${ }^{\text {nd }}$ ed. New York: Columbia University Press, 1950.p. 541.

10 Ibid. 541. see Chap. 22. "Aspects of Fiction", p. 538-567.
To write a good historical novel needs the painstaking research of the historian, the keen analysis and dramatic instinct of the novelist, together with "a gift of creative imagination that can infuse life into the dust of yesterday." 10

Some historical fiction are actually satires masquerading with a plot and characters of the past to parody what is happening in the present. We find this in some of the historical novels of Maha Swe which were written to criticize the British during colonial times.

A common weakness, some critics might even say a serious fault, of historical fiction and its writers is anachronism: an idea, custom, etc. placed in a wrong period of history. For example, in two well-known novels by Min Kyaw entitled Bagan thar [The People of Bagan] ${ }^{11}$ and Htihlaing shin [The Lord of Htihlaing] ${ }^{12}$ Min Kyaw assigns to the Bagan period concepts like democracy, election of leaders, nationalism and so on, which became prevalent in our country only in the twentieth century. Maung Swan Yi has rightly pointed this out in his criticism of Bagan thar printed in Ladu thadinsa [Ladu Daily Newspaper ${ }^{13}$. Maung Swan Yi also noted that the novel Bagan thar is choked with long conversational pieces extolling patriotism, love for the land and country, and other similar concepts. ${ }^{14}$

1 Min Kyaw. Bagan thar. $2^{\text {nd }}$ ed. (Yangon: Sar-thabin Sar-oke Taik, 1974). $1^{\text {st }}$ pub. 1964 12 Min Kyaw. Htihlaing shin. $1^{\text {st }}$ ed. (Yangon: Yamin Sarpay, 1969).

${ }_{13}$ Muang Swan Yi 's book review of Bagan thar, by Min Kyaw. (Mandalay: Ludu Daily, $25^{\text {th }}$ Dec. 1965).

14 Muang Swan Yi. Introductory note entitled "Muang Swan Yi I waiban chet," in Min kyaw. Bagan thar. $2^{\text {nd }}$ ed. (Yangon:Sarthabin Sar-oke Taik, 1974). 6p. no page nos. 
These conversational pieces, which are like long lectures, are in modern prose interspersed with some archaic Myanmar words of the Bagan period.

In Htihlaing shin, there is a scene in which the Lord of Htihlaing, who later became famous as King Kyanzittha (AD 1084-1112), stages a purported coup against his predecessor, King Anawrahta (AD 1044-1077), where Anawrahta rebukes him saying that kingship cannot be taken away by force as he (Anawrahta) had been elected to this position by the people. ${ }^{15}$

Fact and fiction are usually regarded as opposite poles of human perception. The historian works with facts; the novelist creates fiction by using his imagination. But often fact and fiction merge as in the case of the historical novel, so care should be taken to disentangle, if possible, what is actual history and what is the product of the writer's imagination. We have tried to do this with some selected Myanmar historical novels to present what the historical texts relate and how the novelists used that material directly or changed it to suit his or her purpose.

Ledi Pandita U Maung Gyi (1879-1939) was a pioneer in the writing of Myanmar historical novels such as Natshin Naung (1919) and Tabin-shwehtiwuthtu (1924) U Maung Gyi's aim was to rouse the Myanmar youth of colonial times, to remind them of their great leaders of the past, to awaken

15 Min Kyaw. Htihlaing shin. $1^{\text {st }}$ ed. (Yangon: Yamin Sarpay, 1969). p. 246-247.

${ }^{16}$ Dr.Annemarie Esche. "Some Problems of the Historical Novel (A Special Study of Its Development in Burma)", The Guardian [monthly magazine], vol. XX, no. 9 (Sept. 1973)p. 35. national consciousness and pride and to give the Myanmar people a militant courage $^{16}$ to fight against foreign rule.

The first Myanmar historical novel, entitled Natshin Naung, narrates how Natshin Naung, the poet-prince of Taungoo a petty kingdom, falls in love with his cousin-aunt Kaza-datu Kalaya, the daughter of King Bayin Naung of Hanthawady (Hamsavati) and how he gets involved in Hanthawady's military campaigns. The novel, however, is incomplete; the second volume ends with the death of the Hanthawady Crown Prince in the battle against the Siamese and the Myanmar forces retreating from Ayudhya in 1593. It does not cover Datu Kalaya's marriage to Natshin Naung a few years later.

According to the author, the novel was written with the purpose of making the historical personages come alive in its pages and arouse the interest of the reading public in the study of history. Theippan Maung Wa, a critic writing in the columns of the Thuriya (Sun) daily ${ }^{17}$, is well appreciative of the author's efforts. No less a historian than G. M. Trevelyan also has this to say: "Truth is the criterion of historical study; but its impelling motive is poetic ${ }^{18}$."Now how much of the novel is loyal to history and how much fiction is imposed to enthrall the public?

In the novel both the hero and the

17 Theippan Maung Wa. "Yazawin wuthtu mya," by Theippan Kyaung-tha Maung Mya Thwin (pseud.), Thuriya (Sun) daily newspaper $\left(15^{\text {th }}\right.$ Dec. 1928$)$ reprinted in Ngwe-tar-yi, no. 40 (Nov. 1963) p. 37-39.

18 G.M. Travelyan. The Recreations of an Historian. (London: Nelson, 1919). Quoted by A.L.Rowse. The Use of History. (London: Hodder\& Stoughton, 1946). 
heroine are depicted as being attractive and more or less about the same age, to say nothing of their poetic gifts, both being shown as unrivalled poets. They are already drawn to each other before the Hanthawady Crown Prince forcibly takes Datu Kalaya as a wife. But we learn from history that, attractive or not Datu Kalaya was about a dozen or so years senior in age to Natshin Naung and she was no poet either. The one Yadu poem attributed to her in the novel is nothing but the author U Maung Gyi's creation. Besides, she is to quote history again, known to have often attended upon the Crown Prince before the said forcible marriage allegedly takes place. From the literary point of view Natshin Naung is composed in mellifluous prose, but replete with dialogue, maxims and scraps of scholarship impeding the smooth flow of narrative.

The second novel Tabin-shwe-hti wuthtu portrays in four volumes the lifehistory of Tabin-shwe-hti (1531-1550), who together with his brother-in-law Bayin Naung attempted to restore the Myanmar Kingdom to its former glory and who at the height of his power came to a tragic end through an unseem companionship with a foreign adventurer and becoming addicted to alcoholic drink. In the novel are highlighted the activities of Bayin Naung, some of which are not in keeping with the character shown in history and oral tradition. According to these accounts, Bayin Naung is shown as a commoner and son of Tabin-shwe-hti's wet nurse. Both of them and Thakin Gyi (Tabin-shwe-hti's half-sister) have grown up together as children. Young Bayin Naung has an affair with Thakin Gyi and this is reported to the King (Thakin Gyi's father) causing much anger and fury. Bayin Naung is depicted as a merry dare-devil who believes in his destiny, so he coolly, with sangfroid, takes time to watch a cockfight - his favourite pastime - before he goes to see the King and ask for his pardon. But the novel gives a different picture of Bayin Naung in his youth; it presents him as taking refuge with Lawkuttara Sayadaw, the monk well-skilled in the occult, and later bracing himself by carrying charms and amulets when he goes to see and placate the King.

In the novel the conflation of histoy and fiction can be especially noted in the depiction of the following events. History says that on ascending the throne Tabin-shwe-hti decided to have his ear-boring ceremony at the Shwemaw-daw Pagoda in Bago (Hanthawady) located in the midst of enemy territory, and he arranged to be accompanied by some five hundred followers of outstanding courage. The novel adds that as a test of courage each person had to submit himself to having a nail hammered into his thumb, without flinching. Bayin Naung is the first to come out of this test with great aplomb. But this test of courage is not found in any of the Myanmar historical texts ${ }^{19}$. As a work of art the novel has merits as well as demerits similar to the author's Natshin Naung

It may be said that the novel Tabinshwe-hti has moral as well as anticolonialist overtones, for to be a Bama (Burman) is to be a Buddhist as the YMBA (Young Men's Buddhist Association's) credo goes. The same

19 Saw Lu."Chai chai htwin htwin yazawin mu a-taing," Yapyi atwai saung ba mya. (Yangon: Lawka Sarpay, 1998). p. 36. Reprinted from Cherry Magazine, no. 30 (July 1997). 
can be said of the novel Natshin Naung if it could have been continued to its end. True to historical facts the author is likely to conclude the novel with King Anaukphet-lun's victory over and the execution of Natshin Naung for alleged conspiracy with the infidel Philip de Brito of Thanlyin (Syriam) in 1613.

Shwe Set-kya (1912-1978) came into prominence as a historical novelist after Ledi Pandita U Maung Gyi. Among his major works are Nakhan-daw ${ }^{20}(1932)$, A-htauk-taw (1936) ${ }^{21}$ and Konbaung Pyin-thit $(1940)^{22}$.

In Nakhan-daw ${ }^{23}$ are described the last days of Natshin Naung as a backdrop. The hero and the heroine are fictional characters Ye $\mathrm{Hla}$, an official at the Court of Innwa (Ava) and Khin Hnin Nwe, a girl of Portuguese descent as well as a spy in the service of de Brito.

Like much of the Myanmar historical fiction Nakhan-daw is a romance, with a predictable ending. That is to say, the hero and the heroine marry in the final chapter of the book. The story runs thus:

In a male guise Khin Hnin New befriends Ye Hla and stays at his house in Innwa (Ava) as a paying guest. The

${ }^{20}$ Shwe Set-kya. Nakhandaw Wuthtu. $3^{\text {rd }}$ ed. Yangon: Burma Education Extension Association, 1941. (Modern literature series, no.4; General Editor U Pe Maung Tin). Nakhandaw means a "Royal Reporter", i.e. an official of the Hluttaw The King's Supreme Council.

${ }^{21}$ Shwe Set-kya. A-htauk-taw. Yangon: Thuriya Thadinsa Taik, 1936. (Thuriya fiction series, 7).

${ }^{22}$ Shwe Set-kya. Konbaung Pyin-thit. Yangon Myo Chit Press, 1940. latter gradually learns of her gender but without suspecting her of being a spy. Both are secretly in love with each other. Ye Hla then leaves for Bhamo ostensibly to undertake frontier duties, but actually to spy on de Brito, Lord of Than-lyin. He works his way into de Brito's service under an assumed name. But he is informed on by de Brito's wife and incarcerated. Fortunately, Khin Hnin New (now back in Than-lyin) rescues him, revealing her identity. Meanwhile, de Brito attacks Taungoo, bringing back Natshin Naung with him. With Thanlyin under the might of the Myanmar King Anauk-phet-lun, both de Brito and Natshin Naung are executed, the former for being a destroyer of religious monuments and the latter for collaboration with a foreigner. Then the followers of de Brito are, relocated at the Upper Myanmar town of A-myint where Ye Hla is now governor. The novel ends on a happy note in that Ye $\mathrm{Hla}$ and Khin Hnin Nwe are reunited.

Nakhan-daw is purportedly founded on historical sources. But they are mixed with disputed facts. For instance, on the authoriyt of Pawtugi Yazawin ${ }^{24}$ (a minor historical work in Myanmar) Natshin Naung is depicted as having embraced the Roman Catholic faith while in Than-lyin. ${ }^{25}$ The main Myanmar Chronicles are silent on this point. Professor of History U Tun Aung Chain writes that in "its [Pawtugi Yazawin] account of the final episode, some of the details which it provides (...)

${ }^{23} 1^{\text {st }}$ serialized in Thuriya Magazine in $1932.1^{\text {st }}$ ed. in book from 1936.

${ }^{24}$ Pawtugi Yazawin, complied by father Ignazio de Brito and Johannes Moses, a.k.a. Baba Sheen. (Yangon: Thuriya Press, 1918).

${ }^{25}$ Ibid.p.213-16. See also G.E. Harvey. History of Burma... 1925. p.188. 
deserve some attention". ${ }^{26}$

As for the plot, the espionage activities of the hero and the heroine are not much in evidence; instead the love story is in the forefront.

Maha Swe's Sit - htwet - thu (The Fighting Soldier, 1939?) is a novel in two parts - the first one being the love story of Nawade (a poet of the $16^{\text {th }}$ century Myanmar literature) and Shin Hnaung (probably only a fictional character) and the second part relating to the Court of Innwa (Ava), where the iniquitous Shan usurper Thohan-bwa (AD 1527-43) reigns and finally meets with a violent death at the hands of Myanmar patriots. (The hero also plays a significant though unauthenticated role in the assassination plot).

It may, however, be said that there is a thinness about the historical setting and the activities of the hero are rather vague, except for his poems. Lurking behind the façade of the turbulent time of the Thohan-bwa are the author's veiled attacks on the colonial conditions of his day, such as the government's treatment of the natives with contumely, the denial of senior administrative posts to the educated Myanmar, the depressed status of the Myanmar language, the suppression of the Buddhist religion and members of the Sangha, the economic exploitation by the ruling class and by Chinese traders, and so on. In sum, the first part does not mesh with the second to make a harmonious whole.

A historical novel has to be true to the facts of history with the created

${ }^{26}$ Tun Aung Chain "The Pawtugi Yazawin and the de Brito Affair," Myanmar Historical Research Journal, no.9 (June 2002), p.31-44. characters living within the constraints of their time. The characters cannot go beyond the traditions and manners of their period in history, or reality will become distorted ${ }^{27}$.

If Maha Swe's Sit-hwet-thu partially presents a picture of colonial Myanmar, but in a $16^{\text {th }}$ century setting, Dagon Khin Khin Lay's Sarso-daw (1951) must be regarded as partly giving a distorted version of a poet's life at the Court of Mandalay.

The poet is Maung Pe Nge, a cavalry officer in his last appointment. Together with Maung Maung Toke, Commander (of the Northern wing) of the Dawei (Tavoy) Regiment, they are the favourites of King Thibaw (1878-1885). Maung Pe Nge composes a number of romantic poems for himself and also on behalf of some members of the royal family. According to the author, Maung Pe Nge habours a secret love for the beautiful Khin Khin Gyi, and her parents have tacitly agreed to their marriage at an approprite time, but at the command of King Thibaw he helps to arrange an affaire de coeur between the King and Khin Khin Gyi. Speaking as a whole, the events leading to the accession of Thibaw and the dominance of Queen Supaya-lat over her husband occupy more space in the novel than the tragic episode of Maung Pe nge and Khin Khin Gyi.

Incidentally, Thibaw and Supsys-lat are shown as contrasting figures, the one with a weak character and the other, a woman of strong will, who brooks no rival among the palace ladies. The

${ }^{27}$ Rosalind Laker. "Yesterday and Today: Recreating the Past in Historical Novels," The Writer, (May 1990) p.18-20. 
denouement of the novel begins when Supaya-lat comes upon Thibaw dallying with Khin Khin Gyi in the palace garden at the dead of night and finally learns of the love-intrigue. Soon Maung Maung Toke, Maung Pe Nge, Khin Khin Gyi and her family are all arrested by order of the Hluttaw Council and charged with attempts to seize the throne. Then Maund Pe Nge is sent to Bhamo and executed. Before his death Maung Pe nge manages to send a poem to Khin Khin Gyi opening up his love-lorn heart and imporing her to observe the obsequies.

Unfortunately, Khin Khin Gy has already been put to death at the hands of the executioner. It would seem that the conclusion of the novel points to the validity of the saying "Cherchez la femme".

The actual fact according to historical records is that Maung Pe Nge is only on visiting terms with Khin Khin Gyi and her family, but there is nothing of the love-relationship existing between the two of them. Maung Pe Nge himself had long been married to Hinga-maw Myo-sa Mintha-mi (Lady Hinga-maw), had his chief wife and two lesser ones. Besides, he was old enough to be Khin Khin Gyi's father. The aforesaid poem is in reality meant for his chief wife, but in order to build up the tragic climax the author takes the liberty of altering a word or two in the poem so that the addressee becomes Khin Khin Gyi. ${ }^{28}$

The grand style in which the novel is

28 Than swe, U(Dawei). "Taungtaman shindan', Yanant Thit Magazin, no.52 (Aug. 1997)p.151-153; no.63 (Dec. 1998) p.126-129. Also in the Author 's Konbaung shin-dan. Yangon: Sit-the-daw Sarpay; distributed by yapyi Sar-oke Taik, 2001. written hardly compensates for its deficiencies. Sarso-daw is a novel of a datable past, and Dagon Khin Khin Lay herself is a grand-daughter of Wetmasut Wandauk and Naing Khaing Atwinwun (the Royal Librarian U Yan), ex-officials of the Court of Mandalay and has therefore access to information, both written and oral. When complaints were made as to the veracity of the episode, she is said to have replied that she was not writing history but a novel based on historical facts. But it should be borne in mind that genuine facts legitimize historical fiction.

The historical facts distorted by Dagon Khin Khin Lay have been accepted without furthur questioning by later novelists. A writer of Myanmar historical fiction duing the closing year of the $20^{\text {th }}$ century, Seint (Pyin-nya-yei) wrote a popular novel entitled. Daing Khin Khin. ${ }^{29}$ First published in 1976 it has been reprinted four times, the fourth edition appearing in year 2000. This novel is an interweaving of parts of the plot and the mixing of some characters from Dagon Khin Khin Lay's Sarsodaw with the plot and characters of the English novelist F. Tennyson Jesse (1888-1958)'s The Lacquer Lady ${ }^{30}$ where the true story of Mattie Calogreedy, a European maid-of-honour at the Court of King Thibaw and Queen Supayalat, is narrated against the political background of the rivalries and

29 Seint, (Pyin-nya-yei). Daing Khin Khin. 4th ed. (Yangon: Nyaung-yan Sar-oke Taik; distributed by Gon-htu Sarpay, 2000). $1^{\text {st }}$ published 1976.

${ }^{30}$ Fryniwyd Tennyson Jesse. The Lacquer Lady. $1^{\text {st }}$ ed. (London: Heinemann, 1929). There are several translations into Myanmar: by Maung Ne Tun (1967) and Mya Than Tint (1987). 
intrigues between two European colonial powers, the British and the French, which led to the British annexation ofMyanmar in 1886. seint also used $\mathrm{H}$. Fielding - Hall's "Thibaw's Queen". ${ }^{31}$

The picture of Queen Supayalat that Seint paints is harsh: a ruthless, domineering, cruel and jealous woman who is instrumental in putting to death people who displease her. It was on the orders of the Hluttaw (the Myanmar Kings' Supreme Council) that Daing Khin Khin, the poet Maung Hpe Nge and Yanaung Maung Maung Toke were executed. It would be more correct to write that Queen Supayalat was a cunning schemer who had the power and ability to influence the ministers of the Hluttaw to issue the death sentences.

In 1919, U Lat wrote Shwe-pyi-soe, a novel which is set in $19^{\text {th }}$ century Myanmar. The background setting of this novel comprises both the British ruled lower Myanmar region and Upper Myanmar, which at the time was still an independent Kingdom. In the novel can be seen two contrasting pictures: on the one hand, the picture of colonial Yangon with a cosmopolitan population and the modernist activities of the rising landowning and merchant classes, and on the other, monarchical Mandalay where the traditional way of life and the courtly manners of the nobility prevailed.

In the novel are intertwined the lives of the characters belonging to the two parts of the country. What is poignant is the

${ }^{31}$ H. Fielding-Hall. Thibaw's Queen. London :Harper, 1899.

${ }^{32}$ For fuller commentary on Shwe-pyi-soe see Zaw Gyi "Shwe-pyi-soe hnint kyundaw" in Nway-oo kyet-tha-yay hnint kyundaw... reprint 2001. p.81-89. description, full of pathos, depicting the plight of the land-owner father U Yar Kyaw, who has expended almost all his entire fortune on his son Maung Thaung Pe's education in England, vis-a-vis the barrister son in Western dress with swanky airs. It can be said that, despite the fanciful main plot and the plethora of sermonizing passages dotting the novel, it brings to the fore in a vivid way the clash of disparate cultures marking the Myanmar society of the period and is therefore a truthful delineation of an aspect of the social history of the period $^{32}$. U Lat (1866-1921) $)^{33}$ though not a writer of historical fiction per se was an early author of Myanmar novels who ably evoked the atmosphere and the social conflicts prevalent in our country during his younger days.

Thein Pe Myint's Ashe-ga ne-wun htwet thi pamar (As sure as the sun rises in the east) (1953-57) deals with the events of recent memory, relating to the anti-British liberation movement in Myanmar of 1936-1942. It contains a multitude of characters, fictional and real, such as political activists like Kyaw Nyein and Hla Shwe, labour leaders like Thakin Po Hla Gyi, writers like Dagon Taya, and ministers like Dr. Ba Maw. Thein Pe Myint writes that this novel is an eye-witness account. ${ }^{34}$

The hero is Tin Tun - a fictional character whose humble parents have ambitions

${ }^{33}$ For fuller account of U Lat's life and works see Taik Soe "U Lat" in Laik-pya hnint letyway sin sar mya... 2001. p.75-105. Written in 1965.

${ }^{34}$ Thein Pe Myint. "Ashse-ga nne-wun htwet thi pamar hnint kyundaw," in Aung Maw "Thein Pe Myint; wuthtu ta bok hpei ta htok", Sar-oke Lawka, no.7 (July 2002) p.20-22. 
for the son's career in government service. He usually attends classes, flirts with a couple of college girls, enters into extra-marital relations with a married business woman, and becomes a journalist in spite of the parents' wishes; but at the same time he reads political literature and gets caught up in the ebb and flow of politics - such as the students union activities, labour strikes, anti-Indian riots, Japanese activities on the outbreak of World War II, the birth of the Burma Independence Army, and so on. The whole spectrum of Myanmar politics is seen through the eyes of Tin Tun, who plays a minor role in it. But fact and fiction are fused in such a way that the whole work looks both authentic and aesthetically satisfying.

In concluding our paper we would like to give our views on the value that historical fiction has (1) for the general reading public and (2) for students of history.

Good historical fiction written by authors who have undertaken thorough research on the period, the events and the people they are writing about, will bring alive the historical past, bring back the atmosphere, the issues, the feelings, the fears and the gaiety of bygone days. For the general reader this would make history much more interesting than memorizing the dates of historical

${ }^{35}$ Dr.Jim Taylor. "History, Simulacrum and the Real: The Making of A Thai Princess", in From fact to fiction... (Bangkok: Inst.of Asian Studies \& Faculty of Arts, Chulalongkorn University, 2001) p.1.

${ }^{36}$ A.B.Guthrie, jr. "Fiction with a Hold on History," in Highlights of Modern Literature... (New York: The New American Library, 1954.p.203 (Mentor books). happenings which many a school boy or girl has to undergo. Even a low level historical fiction, for example an adventure story set in a particular period of the past, will make readers more interested in the people and events of that time. The best historical fiction crafted by the creative imagination of careful, painstaking writers have now become an accepted form of literature which provides a bridge to straightforward history. For the student of history, good historical fiction is one of the best adjuncts to the historical texts.

History after all is also a narrative of the past based on factual data, the best and most readable historical accounts being born of the perceptive imaginings of what actually happened in the past. Historical fiction can be a good stimulant for the historical imagination. Modern researchers say that our world, past and present, is seen through simulation and simulacra. ${ }^{35}$

These simulations of the historical novel can give us "a knowledge of the dreams and deeds of the men and women who went before". ${ }^{36}$ Thus, historical fiction becomes an essential companion giving "an extra, an inner vision" ${ }^{37}$ to the texts of history providing useful knowledge to both the general reader and to students of history.

As Prof. Daniel Aaron of Harvard wrote: "the best historical novels possess a historical sensibility, the power to reconstruct and inhabit a space in time

${ }^{37}$ Barbara W. Tuchman. Practicing History... (New York: Ballantine Books, 1981).P.46. See especially the essay on "The Historian as Artist," p.45-50. 
past, to identify with it almost vicerally, feel it in their bones and itsessence". ${ }^{38}$

\section{References}

\section{In English}

Aron, Daniel. "The Truths of Historical Fiction," Dialogue, no.100 (Feb. 1993) p.66-71.

Esche, Dr. Annemarie. "Some Problems of the Historical Novel (A Special Atudy of Its Development in Burma)," The Guardian [monthly magazine], vol. XX,no.9 (Sept. 1973) p.34-36 and no. 10 (Oct. 1973) p.31-32.

Fielding-Hall, Harold. Thibaw's Queen London; Harper, 1899.

From Fact to Fiction: History of ThaiMyanmar Relations in Cultural Context. Historical Conference [Proceedings]; ed. by Sunait Chutintaranond [and] Kanokphan U-sha. Bangkok: Institute of Asian Studies \& Faculty of Arts, Chulalongkorn University, 2001. (IAS monographs no. 054).

Haines, Helen E. Living with Books. $2^{\text {nd }}$ ed. New York: Columbia University Press, 1950. Especially Chap. 22. "Aspects of Fiction," p.538-567.

Harvey, G. E. History of Burma... London: Longmans, Green, 1925.

Highlights of Modern Literature ... Essays from the New York Times Book Review; ed. by Francis Brown. New York: The New American Library, 1954. (Mentor books)

Huxley, Aldous. Jesting Pilate, The Diary of the Journey. London:

${ }^{38}$ Daniel Aaron. "The Truths of Historical Fiction", Dialogue, no.100 (Feb. 1993) p.68.
Chatto \& Windus, 1948. (1957 reprint).

Guthrie, A.B., jr. "Fiction with a Hold on history ," in Highlights of Modern Literature...; ed. by Francis Brown. New York: The New American Library, 1954. (Mentor books). p.200-203.

Jesse, Fryniwyd Tennyson. The Lacquer Lady. $1^{\text {s }}$ ed. London; Heinemann, 1929.

Laker, Rosalind. "Yesterday and Today: Recreating the Past in Historical Novels," The writer,(May 1990) p.18-20.

Rowse, A.L. The Use of History. London: Hodder \& Stoughton, 1946.

Taylor, Dr. Jim. "History, Simulacrum and the Real: The Making of a Thai Princess", in From Fact to Fiction; History of Thai-Myanmar Relations In Cultural Context...2001. p.1-15.

Tuchman, Barbara W. Practicing History, Selected Essays. New York: Ballantine Books, 1981. See especially the author's essay on "The historian as artist", p.45-50.

Tun Aung Chain, U. "The Pawtugi Yazawin and the de Brito Affair," Myanmar Historical Research Journal, no.9 (June 2002), p.31-34. Trevelyan, G.M. The Recreations of an Historian. London: Nelson, 1919.

\section{In Myanmar}

Hman-nan Maha Yazawin-daw-gyi (The Glass Palace Chronicle). Mandalay: Mandalay Pitaka abook Depot, 1936. 3 vols.

Jesse, Fryniwyd Tennyson. The lacquer lady, translated by Mya Than Tint under the title Chit-thaw Yun Khin Khin. Ynagon: Pyi-thu Sar-oke Taik, 1987. 3vols. Distributed by 
Aung Mi-tha- su Sar-pay Hpyantchiyei.

Kala, U Maha Yazawin-gyi ...Burma Research Society edition Yangon: Hanthawaddy, 1960-61 (reprint). 3 vols. $1^{\text {s }} 2$ vols. edited by Saya Pwa for the Burma Research Society ; vol.3 edited by U Khin Soe for the Hanthawaddy Press. Vol.(1) $1^{\text {st }}$ pub. 1926, vol. (2) $1^{\text {st }}$ pub. 1932 by the Burma Research Society.

Khin Khin Lay (Dagon). Sarso-daw nan-dwin wuthtu-gyi. Yangon: Burma Khit Press, 1951. 3 vols. Reprint in 1 vol. $3^{\text {rd }}$ ed. Ynagon: Sarpay Mwe-thu Sarpay Taik, 1975. With some revisions.

Onbaung-zet Maha Yazawin-daw-gyi $\ldots 3^{\text {rd }}$ ed. Yangon: Ledi Mandaing Press, 1968. $3 \mathrm{v}$ ols. $1^{\text {st }}$ published. 1921.

Lat, U. Shwe-pyi-soe wuthtu, by Pyawdaw hset [pseud .] $1^{\text {st }}$ ed. Yangon: Myanmar-pyi Budha Sasana-pyu Sarpon-nheit Taik, 1914. $2^{\text {nd }}$ ed., edited by Saya Wa. Yangon : Burma Research Society, 1932.

Maha Swe, Sit-hwet-thu; ed. [with intrtod.] by Thuriya U Thein Maung. Yangon: Daw Ohn Thin and Sons, 1939. $2^{\text {nd }}$ ed. Yangon: Shumawa, 1961.

Maung Gyi, $U$. (Ledi pantida). Tabinshwe-hti wuthtu-taw-gyi. [3 $3^{\text {rd }}$ ed.] Yangon: Thitsa-mon Sarpay, 1991. This ed. wrongly printed as $2^{\text {nd }} e d$. (2 ${ }^{\text {nd }}$ ed. 1958). $1^{\text {st }}$ ppub. By Dagon Press, 193-.

Min Kyaw.[pen-name of U Kyaw Swe]. Bagan thar. $2^{\text {nd }}$ ed. Yangon:Saroke Taik, 1974. $1^{\text {st }}$ pub. 1964.

Min Kyaw. Htihlaing shin. $1^{\text {st }}$ ed. Yangon: Yamin Sarpay, 1969.

Shay-haung Mon Kyauksa baungchok [Collection of Mon inscriptions]; ed. and trs. By U Chit
Thein. Yangon: Archaeology Dept., 1965.

Paragu [pen-name of U Hla Kyaing]. "Thamaming nauk-khan Myanmar wuthtu," in Wuthtu shay sardan mya, vol. 1. Yangon: Sarpay Beikman, 1981, p.76-128.

Pawtugi Yazawin [History of the Portugese]; complied by Father Ignazio de Brito and Johannes Moses, a. k. a. Baba Sheen. Yangon: Thuriya Press, 1918, Written in early $19^{\text {th }}$ century.

Saw Lu [Pen name of U Saw Tun]. "Chai chai htwin htwin yazawin mu ataing," Yapyi atwai saung-ba mya. Yangon: Lawka Sarpay, 1998. p.32-41. Reprinted from Cherry Magazine, no.30 (July 1997).

Seint (Pyin-nya-yei). Daing Khin Kkhin . 4th ed. Yangon: Nyaungyan Sar-oke Tiak; distributed by Gon-Htu Sarpay, 2000. $1^{\text {st }}$ pub. 1976.

Shwe set-kya. Ahtauk-taw . Yangon: Thuriya Thadinsa Taik, 1936. (Thuriya fiction series, 7).

Shwe Set-kya. Konbaung Pyin-thit. Yangon: Myo Chit Press, 1940.

Shwe Set-kya. Nakhandaw Wuthtu. $3^{\text {rd }}$ ed. Yangon: Burma Education Extension Association, 1941. (Modern literature series, no. 4; General Editor U Pe Maung Tin).

Swan Yi, Maung . (pen-name of U Ein Pe). "Maung Swan Yi I wai-banchet," in Min Kyaw. Bagan thar. $2^{\text {nd }}$ ed. Yangon: Sar-thabin Sar-oke Taik, 1974.6p. no. page nos. Reprinted from Mandalay: Ludu Daily (25 $5^{\text {th }}$ Dec.1965).

Taik Soe (pen-name of U Than Htut). Laik-pya hnint let-yway-sin sar mya. Yangon: Shwe Sarpay Taik, 2001. See essay on U Lat, written in 1965, p.75-105. 
Taungoo Yazawin; complied by shin Nyana-thi-khan-gyi; ed. by Saya Pwa. Taungoo: Kaytumadi Press, 1924.

Than-lyin Yazawin [History of Syrium]. Yangon: Thitsawardi Thadinsa Press, 1925.

Than Swe, U (Dawal). Konbung shindan Yangon: Sit-the-daw Sarpay; distributed by Yapyi Sar-oke Taik, 2001.

Thein Pe Myint. Ashe-ga-ne-wun htwet thi pamar. $8^{\text {th }}$ ed. Yangon: Sar-oke Zay, 2001. 2 vols. $1^{\text {st }}$ serialized in Myawaddy (monthly) magazine, (June 1953-Oct. 1957). $1^{\text {st }}$ pub. In book from 1958 (this ed. designed $2^{\text {nd }}$ ed. by author). See also the author's "Ashe-ga ne-wun htwet tapamar hnint kyundaw", in Aunt Maw "Thein Pe Myint in wuthtu tabok hpei ta htok, Sar-oke lawka", no.7 (July 2002), p.20-22.
Tin Htun, U. Yazawin saing-yar Myanmar mya (1885-1947). (Myanmar novels about history, 1885-1947). Unpublished M.A. in Myanmar Literature thesis. Yangon: University of Yangon, 1982.

Wa, Maung, Theippan. "Thibaw min nan-dwin yei", in Man ya pyi. Mandalay: Mandalay Centenary Celebrations Committee, 1959. p.132-136. Reprinted from Thuriya Magazine (Nov. 1939).

Wa, Maung, Theippan.'YYazawin wuthtu mya ," by Theippan Kyaung-tha Maung Mya Thwin (pseudo.), Thuriya (Sun) daily newspaper (15 ${ }^{\text {th }}$ Dec. 1928). Reprinted in Ngwe-tar-yi, no.40 (Nov. 1963) p.37-39.

Zaw Gyi (pen-name of $U$ Thein Han).Nway-oo Kyet-tha-yay hnint kyundaw. Yangon: Shwe Sarpay Taik, 2001. See essay "Shwe-pyisoe hnint kyundaw”, p.81-89. 